http://kitaibelia.unideb.hu/

ISSN 2064-4507 (Online) • ISSN 1219-9672 (Print)

(C) 2015, Department of Botany, University of Debrecen, Hungary

20 (2): 179-192.; 2015

DOI: $10.17542 /$ kit.20.179

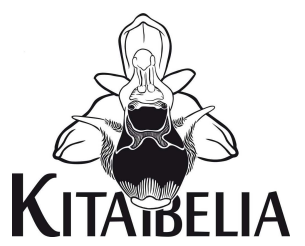

\title{
180 éve született dr. Waisbecker Antal
}

\author{
BALOGH Lajos $^{1 *}$ \& KeSZEI Balázs ${ }^{2}$ \\ (1) Savaria Múzeum, Természettudományi Osztály, H-9700 Szombathely, Kisfaludy Sándor u. 9. * \\ balogh.lajos@savariamuseum.hu \\ (2) Jurisich Miklós Gimnázium, H-9730 Kőszeg, Hunyadi János u. 10. keszeib@jurisich-koszeg.sulinet.hu
}

\section{Dr. Antal Waisbecker was born 180 years ago}

\begin{abstract}
Dr. Antal Waisbecker (1835-1916) was a Hungarian physician and the most prominent botanist of Vas county (West Hungary) at the turn of the 19-20 th century. He contributed with important floristic data for the botanical monography of Vas county, authored by Vince Borbás. He processed the pteridophytes of Vas county and cormophytes in the surroundings of Köszeg. Antal Waisbecker was an expert in the knowledge of sedges too. He discovered and described the Carex fritschii. Remarkable amount of herbarium specimens collected by Waisbecker are deposited at the Savaria Museum (Szombathely, SAMU) and Hungarian Natural History Museum (Budapest, BP).
\end{abstract}

Keywords: botanist, herbarium, Hungary, Kőszeg, museum, physician, Szombathely, Vas county

Összefoglalás - Dr. Waisbecker Antal Vas vármegye tisztifőorvosa és a XIX-XX. század fordulóján a megye legjelentősebb botanikusa volt. A megye botanikai monográfiáját jegyző Borbás Vincét is jelentős florisztikai adatokkal segítette. Tanulmányaiban többek között feldolgozta Vas megye harasztjait és Kőszeg vidékének edényes növényeit. Érdemeket szerzett a sások ismerete terén, különösen a Carex fritschii leírásával. Adományozott növénygyűjteményével a Vasvármegyei, ma Savaria Múzeum Természettudományi Osztályának egyik alapítója (SAMU). Gyűjteményének másik része a Magyar Természettudományi Múzeum Növénytárában (BP) található.

Kulcsszavak: botanikus, herbárium, Kőszeg, múzeum, orvos, Szombathely, Vas megye

„Köszeg és vidékének növényzete oly dus és oly változatos, hogy nemcsak a sétálót gyönyörködteti, szivére lelkére épp ugy mint testére üditőleg hat, de a Florista figyelmét is csakhamar leköti, sok olyan növény alakra bukkanván, mely hazánk más vidékén sôt a külföldön is ritkán vagy éppen nem található; ..."

A fenti szavakkal kezdte Dr. Waisbecker Antal „Kőszeg és vidékének edényes növényei” című munkáját, melyet második, bővített kiadásban 1891-ben adatott ki Kőszegen. Gondolkodását áthatotta a kissé szubjektív, ám messzemenően jó szándékú és mértékletes lokálpatriotizmus. Botanikai tevékenysége majdnem kizárólag Kőszeg vidékére szorítkozott, annak növényeit és növényzetét kiválóan ismerte. Lakóhelyéről ritkán távozott s ekkor is leginkább a gyógyulást keresve. Így botanizált Tátrafüreden, Gleichenbergen és ezenkívül egyszeregyszer az Alpok Kőszeghez közeli keleti nyúlványán a Rax-hegységben és a Celldömölk melletti Sághegyen. Életéről és munkásságáról több méltatás is született, így például: VENDE 1898, DEgEn 1914, ANONYM 1916a-e, 1918, 1937, 1986, CHERNEL 1916, GÁYER 1916a, 1929a, KÜMMERLE 1916a, MÁGOCSY-DietZ 1916, JÁVORKA 1917, Kiss 1958, B. IMREH 1985, Tóth 1991, BARTHA 1994a, MERKLIN 1997, VIG 1999, BALOGH 2002, 2006, 2010a,b. Botanikusi szakkörökben alig ismert életrajza (THIRRINGNÉ 1935) a közelmúltban került újraközlésre BALOGH et al. (2005) tanulmányának vonatkozó részeként. 


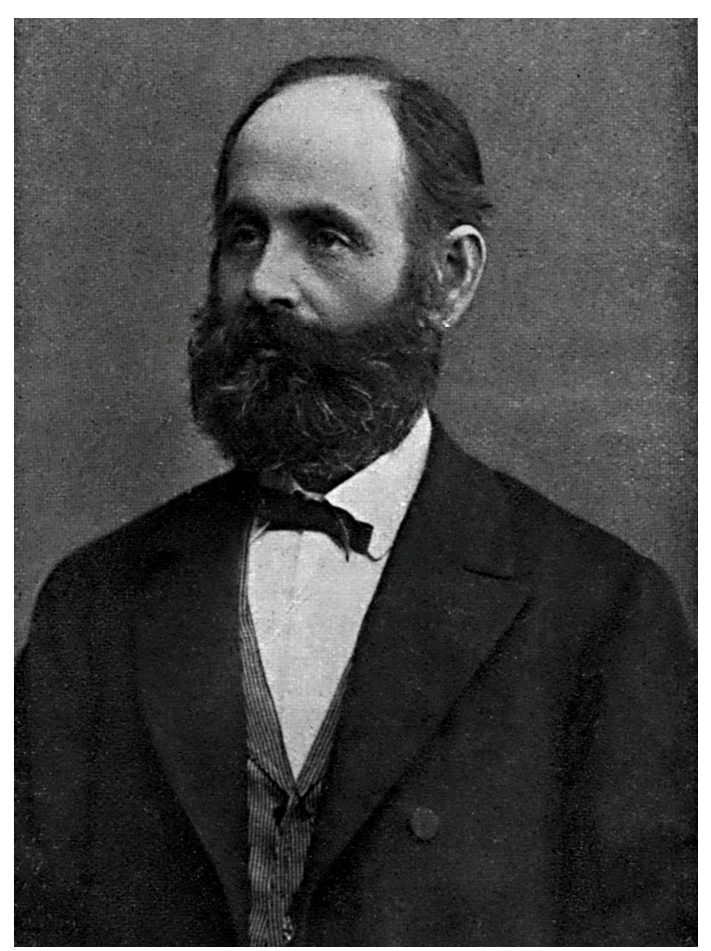

1. ábra. Dr. Waisbecker Antal

Fig. 1. Dr. Antal Waisbecker

\section{A családi kapcsolatok}

A magánéleti viszonyokat tekintve dr. Waisbecker Antal és családjának legteljesebb életrajzírója lánya, Waisbecker Irén (1868-1957), a Kőszeg, Szombathely és környékük útikalauzait (THIRRING 1928, 1933) is megíró dr. Thirring Gusztáv felesége volt (THIRRINGNé 1935, 1937, 1938). A Waisbecker család a németországi Orbból, a Frankfurt am Main melletti kisvárosból származott. THIRRINGNé (1935) szerint a XX. század elején, az eredetileg Weisbecker-nek írt családnév itt igen elterjedt volt. Waisbecker Henrik, aki Orbban született 1763-ban, valószínűleg a napóleoni háborúk előtti zűrzavaros viszonyok miatt keletebbre, Magyarországon keresett boldogulást. Ő és fiai is kereskedők voltak. A család német származása azért is figyelmet érdemlő, mert az ifjú Waisbecker Antalt Bécsben, egy ízben rövid időre börtönbe is zárták, pörge magyar kalapjáért és túlságosan magyaros beszédéért.

Waisbecker Antal Kőszegen született 1835. január 29-én. Négyéves korában került az elemi iskolába, valójában azért, hogy leköthesse érdeklődését, életrajzírója szerint, hogy „ülni tanuljon". A kis fiúcska azonban oly élénk eszü volt, hogy a két évvel idősebbekkel végezte az osztályokat és fizikálisan kicsi ember létére is megbirkózott a tudományokkal. Alacsony termetű ember volt, rendkívül kicsiny koponyával. Magas homloka, élénk, figyelő szeme azonban elárulta nem közönséges intelligenciáját (vö. ANONYM 1916f, 1968; 1. ábra). 16 és fél éves volt, amikor a kőszegi és szombathelyi iskoláztatás után Sopronban érettségizett. Az 1677ben alapított kőszegi bencés gimnázium (Vas megye legrégebbi gimnáziuma) mindig kitűnő nevelőiskolának bizonyult, hazafias irányát nem tagadta meg soha. Mély benyomást tett az ifjúra gimnazista korában a Kőszegen 1849 áprilisában egyszerủ szekéren átvonuló 
fogoly Batthyány Lajos, Magyarország első felelős miniszterelnöke, akit a diákok - az utcán sorakozva néma főhajtással üdvözöltek. Megrázta édesapjának súlyos sebesülése a kőszegi polgárok és Jellasics horvát bán egyik csapatának kőszegi összecsapása alkalmából. Az 1848-49-es szabadságharc történéseit később hitelesen megismerte Görgey Artúr adjutánsától, Rochlitz Kálmántól, aki vele együtt végezte az orvosi tanulmányokat Bécsben (THIRRINGNÉ 1935).

1858-ban Bécsben avatták orvosdoktorrá. Egy ideig egy ottani közkórházban, nyáron pedig a horvátországi Lipik (Pozsega vármegye) fürdőjében dolgozott. Kiváló orvosi munkásságát már a bécsi kórház igazgatósága is kiemelte, így külön köszönetet kapott a helytartóságtól és a kórház vezetőitől önfeláldozó működéséért az 1858-59. évi bécsi tífuszjárvány idejében. Heim Tivadar, a kórház akkori igazgatója, sajátkezú írásban emelte ki nagy szorgalmát, igen magas erkölcsi felfogását és magatartását. Rendkívüli nyelvképességéről tanúskodtak könyvtárának francia, olasz, angol nyelvű könyvei, amely nyelveken „csak” olvasott, latinul azonban folyékonyan beszélt úgy, mint magyarul. Szintén anyanyelvi szinten beszélt, írt és olvasott németül és horvátul is. 1861-ben tért vissza szülővárosába, ahol Kőszeg szabad királyi város tiszti főorvosává választották.

1864-ben feleségül vette Szovják Emíliát (18391914), akivel aranylakodalmukat is megünnepelhették. Két fiuk és három leányuk született. Sorrendben Szidónia, Jenő, Irén, Margit és Gyula. Gyermekeiket

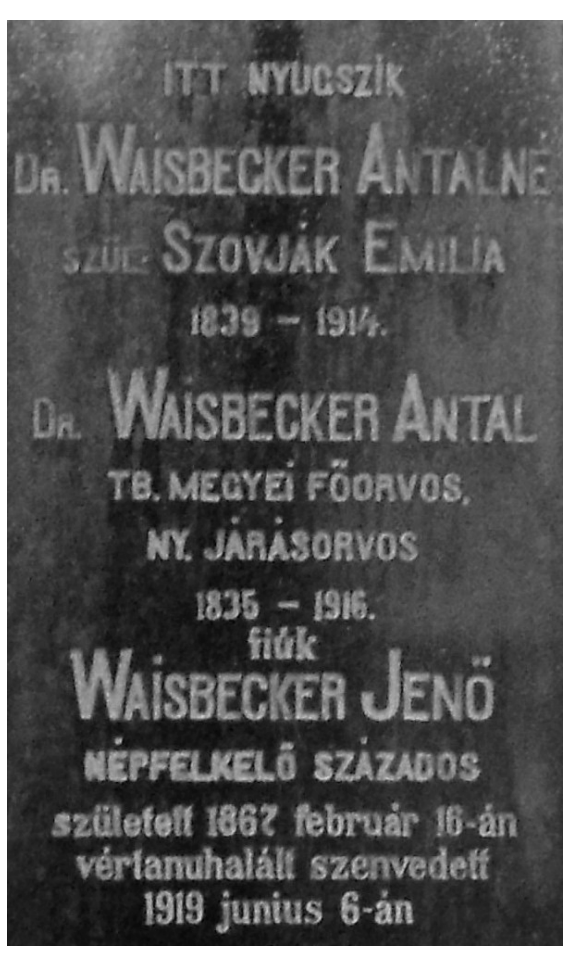

2. ábra. Dr. Waisbecker Antal és családja síremlékének felirata a kőszegi temetőben (Keszei Balázs felvétele).

Fig. 2. Inscription of the tomb of Dr. Antal Waisbecker and his family in the cemetery of Kőszeg (photo by Balázs Keszei). szerető gondoskodással - a fiúkat római katolikusként, a leányokat evangélikusként vallásosan - nevelték (THIRRINGNÉ 1935). [Idősebb fiuk, dr. Waisbecker Jenő 1915-től kezdődő katonai frontszolgálata után a századosi rangot kiérdemelten, 1919. június 6-án éppen szabadságon volt Kőszegen. Hazaszeretettől izzó és büszke nemzeti öntudattól áthatott beszédet mondott a városháza előtt. Az egybegyűlt tömeg nagy lelkesedéssel és kitörő örömmel hallgatta városa fiának szavait. Az eseményt követően Waisbecker Jenő és Hersics György velemi bíró a Tanácsköztársaság áldozatai lettek (THIRRING 1928).]

Dr. Waisbecker Antal 1870-ben Vasvármegye tiszteletbeli fóorvosa, 1872-ben pedig Vasvármegye kőszegi járásának tiszti járási orvosa lett s ezt a feladatot látta el egészen 1896ig. Ebben az évben betegsége miatt nyugalomba vonult. Fiatal kora óta gyomorfekélytől származó gyomortágulásban, krónikus máj- és epebántalmakban szenvedett, olyannyira, hogy ötven éves korától fogva jóformán csak híg táplálékkal élt. Hatvan évesen súlyos légcsőbántalmak fokozták bajait, így szinte csodálatos volt az az életenergia, amely a beteg szervezetet munkaképessé tette. Idős korára egy nem operálható hályogbetegsége miatt sajnos a botanikáról is le kellett mondania. Haláláig szinte kizárólag a családjának élt. 1916. április 4-én hunyt el Kőszegen, ott is nyugszik (2.ábra). 


\section{A közéleti személy}

Már orvosi egyetemista korában érdeklődött az ének-zene, a sport és az orvosi növénytan iránt. Szülővárosában - orvosi működése mellett - a közélet kulturális részét mind több irányban igyekezett ápolni, segíteni. E gondolatokkal léphetett be szervezőnek, alelnöknek, majd elnöknek a kőszegi Concordia dalegyletbe. Az egyesületet a XIX. századi polgári öntudat fejlődése és a polgárság művelődésének igénye hozta létre. (A jelenleg is működő ConcordiaBarátság Énekegyesület az 1859-ben alapított Concordia és az 1962-ban alakult Barátság kórusok 1985-ben történt egyesítésével jött létre.)

Létrehozta és első elnöke lett az első rendszeresített kőszegi tűzoltószervezetnek, amely a ma is működő Kőszegi Önkéntes Túzoltó Egyesület elődje volt. Ez Magyarország „legrégibb” önkéntes tűzoltó egyesülete. Közreműködött a hegyközség létrejötténél, a gyümölcs- és szőlőnemesítésre fektetve a fősúlyt. Ebben nyilvánvalóan inspirálta az a tény, hogy a - világon egyedülálló módon - Kőszegen 1740 óta létezik a Szőlő Jövésnek Könyve, amelybe minden évben Szent György napján (április 24-én) vízfestményeken örökítik meg a különböző dűlőkből a polgármester elé hozott szőlőhajtásokat, „jövéseket”. Abban az időben a hajtások nagysága és a termés mennyisége és minősége közötti kapcsolatokat keresték.

Waisbecker minden lehetséges fórumon szót emelt az erdők fenntartása, az utak fásítása érdekében. Hozzájárult a (szintén mai is működő) Kőszegi Polgári Kaszinó és könyvtára létrejöttéhez, ahol később elnökölt is (THIRRINGNÉ 1935).

Anyagi körülményei lehetővé tették, hogy Deák Ferenc (Kőszeg Város díszpolgára) emlékére alapítványt tegyen német fiúk magyar nyelvű nevelése, tanítása érdekében (SöPTEI 2000). 1868-tól 1900-ig az akkor alapított kisdedóvóért is dolgozott. Elkészítette az alapszabály tervezetét, amely a „gyermekkert” megalakulásának alapja volt. Legtovább mint pénztárosa, majd mint alelnöke, végül mint elnöke és a választmány tagja vett részt az óvoda igazgatásában. Figyelme kiterjedt éppúgy az óvoda berendezésére, mint a megfelelő óvónő (gyermekkertésznő) kiválasztására is.

Ez időben az első magyar polgáriskoláért is dolgozott, előbb az iskolaszék alelnöke, majd elnöke volt. Különös gonddal rendezte be ez iskola könyvtárát, súlyt helyezett a gyermekek testnevelésére, és elsőként honosította meg a leányok tornatanítását.

Waisbecker Antal fiatal korában maga is kitűnő sportoló volt. A torna szeretete megmaradt és a víz alatti úszásban is jeleskedett. Jó hegymászó is volt, aminek a botanikában is hasznát vette.

Mint orvos jelentősen támogatta a gyermekápolást és a bábaképzést, kortársait ezzel jóval megelőzve. A Hosszú Élet, Közegészségügyi Kalauz, Orvosi Hetilap vagy a Vasmegyei Lapok hasábjain közölt orvosi cikkei is főleg ilyen, közegészségügyi téren íródtak. A gyermek, a kisgyermek megfigyelése volt egyik életöröme. Unokáival még 70 éves korában is bújócskást játszott, a nagyobbakat pedig séta közben a természet szépségére tanította - írta leánya (THIRRINGNÉ 1935).

\section{A botanikus}

Már majdnem ötven éves volt, amikor igazán komolyan kezdett foglakozni a botanika tudományával, és egy évtized sem múlt el, s már a közismert, sőt európai szinten is számon tartott botanikusok közé tartozott. Dr. Gáyer Gyula így méltatta emlékezésében (GÁYER 1916a): „Kőszeg flórája pedig elveszítette leghivatottabb interpretátorát, kinek múködése gyönyörü példája annak, hogy a szükös vidéki viszonyok között is, távol a botanikus központoktól türelmes és lelkiismeretes munkával mégis lehet maradandót alkotni." 


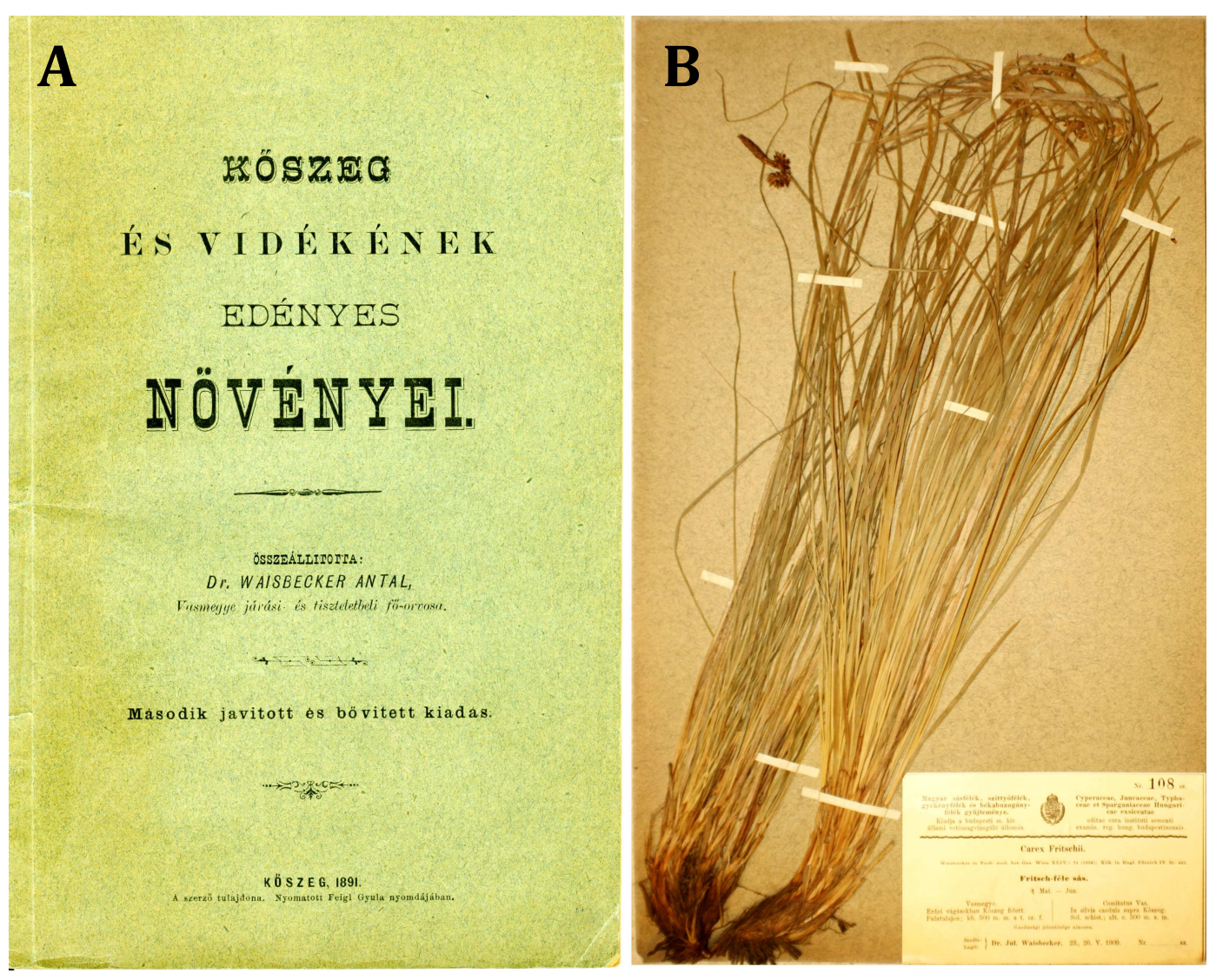

3. ábra. Waisbecker kőszegi flóraművének második kiadása (A). A Carex fritschii Waisb. egy lapja a Magyar sásfélék, szittyófélék, gyékényfélék és békabuzogányfélék gyưjteményéből (B).

Fig. 3. Second edition of Waisbecker's Flora of Kőszeg (A). One of the specimens of Carex fritschii Waisb. from the Cyperaceae, Juncaceae, Thyphaceae et Sparganiaceae Hungaricae exsiccata (B).

Dr. Waisbecker Antal - Freh Alfonz (1932-1918) bencés rendi gimnáziumi tanár és Piers Vilmos (1838-1920) őrnagy, katonai alreáliskolai tanár mellett - a XIX. század végén és a XX. század elején, Kőszegen élte tehát életét és fejtette ki jeles botanikai tevékenységét. A híres botanikus triász későbbi tagjaként a növénytannal akkor ismerkedett meg közelebbről, mikor legidősebb fiának - akinek éppen Freh Alfonz volt a tanára - herbáriumot kellett összeállítani. Waisbecker felismerte, hogy a Freh első munkájában (FREH 1876) rögzített 666-nál jóval több növényféle él Kőszeg környékén. Így nagy lendülettel vetette bele magát botanikai tanulmányaiba. Mikor Borbás Vince (1844-1905) 1882-ben hozzáfogott vasvármegyei flóraművének megírásához, Waisbecker elérkezettnek látta az időt a városa környéki flórára vonatkozó ismereteinek kiadásához. Ennek első összegzése a Kőszeg és vidékének edényes növényei (WAISBECKER 1882), melyben 1018 taxont sorolt elő. [Nem 1008at, miként e szám a kezdetektől (BORBÁs 1887, CHERNEL 1916, GÁYER 1916 stb.) a közelmúltig (BARTHA 1994a, KovÁCS 1997 stb.) pontatlanul szerepelt, továbbá nem fajt, ahogy ez régtől (CHERNEL 1916, GÁYER 1916 stb.) gyakorta (BARTHA 1994a, KovÁcs 1997 stb.) szintén tévesen említtetett, noha Vas megyei művében BoRBÁs (1887) sem 1008 fajt, hanem növényt említ WAISBECKER (1882) munkájából.] A tudóstársak nemes versengése jegyében egy év múlva Freh már 1116 taxont ismertetett (FREH 1883). Waisbecker 1891-ben jelentette meg múve 
második kiadását (WAISBECKER 1891b), amelyben már 2098 fajt és eltérést közölt. Az elsőnél jelzetthez hasonló kritikával kezelendők ez utóbbi kiadás adatainak szakirodalmi említései is. Ehhez jön még, hogy a számadatok a mai taxon-értékeléshez képest is túlzóak (JEANPLONG 1981). Itt említhető meg, hogy a Waisbecker veje által jegyzett kőszegi útikalauzban (THIRRING 1928) a környék növényvilágának ismertetése Waisbecker Antal posztumusz közléseként szerepel (WAISBECKER 1928). A botanikus triász harmadik tagja, Piers Vilmos gyakorlatilag nem, vagy alig (PIERs 1890) publikált, így az ő munkásságának eredményei csak herbáriumi adatainak idézésével épülnek be a szakirodalomba (BALOGH et al. 2004).

Waisbeckernek az 1890-es évek elejétől aztán folyamatosan jelentek meg dolgozatai, előbb elsősorban az Österreichische Botanische Zeitschrift-ben (WAISBECKER 1891a, 1892, 1893a, 1895, 1897a, 1898a, 1899a,b, 1901a), majd a lap 1902-es indulásától a Magyar Botanikai Lapok-ban (WAISBECKER 1902, 1903, 1904, 1905, 1908), illetve közben a Természettudományi Közlöny (WAISBECKER 1890), a Verhandlungen der zoologischbotanischen Gesellschaft in Wien (WAISBECKER 1894), az Allgemeine Botanische Zeitschrift (WAISBECKER 1897c,d, 1898b, 1901c), valamint a Természetrajzi Füzetek hasábjain is (WAISBECKER 1901b).

A már korában is sokak által kiváló floristának tartott Waisbecker sok új adattal gyarapította Kőszeg és általában a Vas megyei hegyvidék flóráját (BORBÁs 1882, 1887, 1898, GÁYER 1916a,b, GoмBocz 1936). Borbás Vasvármegye növényföldrajza és flórája (1887) címü könyve is az őt gyakran kalauzoló Waisbecker számos, elsősorban Kőszeg környéki adatát tartalmazza. Cikkeiben több adventív-megfigyelést is közöl, például az Aster salignus patakparti előfordulását Rohoncon (WAISBECKER 1895), vagy herbáriumából jeleznek ilyet, mint az Eragrostis mexicana esetében (JÁVORKA 1929). Tehetségének egyik legszebb bizonyítéka a Willemetia stipitata (Jacq.) Dalla Torre [syn.: Calycocorsus stipitatus (Jacq.) Rauschert] esete, ahol pontos vizsgálatával az akkori ország flóráját egy új nemzetség előfordulásának megállapításával gyarapította (WAISBECKER 1890, 1904); a lelőhely ma ausztriai (burgenlandi/őrvidéki) területre esik.

Taxonómiai munkásságából talán legjelentősebb a Vasvármegye harasztjaival foglalkozó cikksorozata (WAISBECKER 1902, vö. még WAISBECKER 1898a, 1899a, 1901a, 1903, 1904). GoмвосZ (1936) szerint Kümmerle Jenő Béla (1876-1931) és Győrffy István (1880-1959) mellett Waisbecker Antal a XX. század elejének egyik legjelentősebb hazai harasztkutatója volt. Pteridológiai tevékenységének és szakirodalmi utóéletének részletes elemzése herbáriuma Szombathelyen őrzött harasztjainak ismertetésében szerepel (BALOGH et al. 2005), amiból ezúttal csak néhány mozzanatot emelünk ki.

Waisbecker kora számos hazai és külföldi botanikusával kapcsolatban állott, némelyikkel élénk levelezést folytatott. Így például a külföldi harasztkutatók köréből a königsbergi Christian Luerssen (1843-1916), vagy a berlini Paul F. Ascherson (1834-1913) emelhető ki. Utóbbi, Graebnerrel írt közép-európai flórájában szerepelteti a Waisbecker által leírt hibrideket, a kőszegi botanikus számos varietas-át és forma-ját is (ASCHERSON \& GRAEBNER 1912).

Az egykori Vas vármegyének ma Ausztria területére eső részéről számos florisztikai adatot közlő Waisbeckerre az osztrák floristák ritkán hivatkoznak (LÄMMERMAYR 1928, MELZER 1962), inkább csak egyes bibliográfiák ismertetik publikációit (AUMÜLLER 1956, LITSCHAUER 1964, SAUERZOPF 1983). Az osztrák határozókönyv mint Kőszeg/Güns (Burgenland) kutatóját említi (FISCHER \& ADLER 1994), későbbi kiadása azonban már nem (FISCHER et al. 2005). Figyelemreméltó viszont, hogy Vasvármegye harasztjai címú múvét (WAISBECKER 1902) a Hegi-féle Illustrierte Flora von Mitteleuropa újabb kiadása az Asplenium nemzetségnél a fontosabb irodalmak közt idézi (DosTÁL et al. 1984). A hazai 
szakirodalomban a Waisbecker által leírt haraszt-hibrideket, -varietasokat és -formákat utoljára Soó (1964) Synopsisa hozza, utóbbiakat KIRÁLY (1996) is idézi.

Taxonómusként a virágos növények körében néhány új faj, több hibrid és számos faj alatti taxon leírása füződik Waisbecker nevéhez (részben Borbás Vincével). Az eredetileg fajként leírt taxonok a mai érvényességi viszonyokat tekintve a Carex fritschii kivételével többnyire hibridek, illetve változatok (varietas-ok). Korabeli és újabb neveiket THIRRINGNÉ (1935) és PRISZTER (1985) nyomán az 1. táblázat tartalmazza. Waisbecker alapos felkészültségét bizonyítja, hogy magabiztosan mozgott a nehezebb nemzetségek terén is, mint a Rubus (WAISBECKER 1893a, 1895, 1897a), Potentilla (WAISBECKER 1892, 1895, 1897a, 1901a), Viola (WAISBECKER 1893b, 1895, 1901a), Cirsium (WAISBECKER 1899a, 1901b), Mentha (WAISBECKER $1893 a, 1895)$ stb. Legszebb felfedezése a dunántúli sás (Carex fritschii Waisb.) - melynek tudományos leírását Kőszeg környékén gyűjtött egyedekről adta meg - is ebbe a kategóriába tartozik (WAISBECKER 1894, vö. még WAISBECKER 1897a-d, 1898b, 1899a, 1901a,c, 1904, 1905, GÁYER 1916a, JÁVORKA 1940). Waisbecker egyébként több mint félszáz edényes virágtalan és közel háromszáz virágos infraspecifikus taxont írt le, amelyek jegyzékét KÜMMERLE (1916b) kézirata tartalmazza.

1. táblázat. A Waisbecker (és Borbás) által fajként leírt taxonok és újabb nevük.

Table 1. Taxa and their recent names described as species by Waisbecker (and Borbás).

\begin{tabular}{|c|c|}
\hline Eredeti név / Original name & Érvényes név / Valid name \\
\hline Carex Fritschii Waisb. & C. fritschii Waisb. 1894 \\
\hline Viola commutata Waisb. & V. $\times$ commutata Waisb. 1895 (montana $\times$ pumila) \\
\hline Viola tristicha Waisb. & V. nm. $\times$ tristicha Waisb. 1895 (mirabilis $\times$ sylvestris) \\
\hline Potentilla Ginsiensis Waisb. & $\begin{array}{l}P . \times \text { ginsiensis Waisb. } 1891 \\
(\text { arenaria } \times \text { pusilla; } ? \text { P. vindobonensis Zimm. 1884) }\end{array}$ \\
\hline Rubus Borbasiellus Waisb. [1897] & érvényessége kérdéses \\
\hline Rubus trichotecus Waisb. & $\begin{array}{l}R . \times \text { trichotecus Waisb. } 1893 \\
(\text { canescens subsp. lloydianus } \times \text { pubescens })\end{array}$ \\
\hline Rubus Rötensis Waisb. & $\begin{array}{l}\text { R. micans Godr. } 1848 \text { subsp. pulcher (Lef. et Müll. 1859) Sudre } \\
1911 \text { var. roetensis (Waisb. 1897) Sudre } 1911\end{array}$ \\
\hline Rubus lasiaxon Borb. et Waisb. & $\begin{array}{l}\text { R. colemannii Bloxam } 1850 \text { subsp. gremlii (Focke 1877) Sudre } \\
1910 \text { var. lasiaxon (Borb. et Waisb. 1893) Sudre } 1918 \text { / KIRÁLY } \\
\text { Gergely (in e-litt. 2015. okt. 30.) szerint = Rubus ferox Vest 1823, } \\
\text { továbbá: Waisbecker Rubus-taxonnevei nem érvényesek, } \\
\text { általában egyedi morfotípusokra vonatkoznak. }\end{array}$ \\
\hline $\begin{array}{l}\text { Rubus porphyropetalus } \\
\text { Borb. el Waisb. [1893] }\end{array}$ & érvényessége kérdéses \\
\hline Mentha Steffekiana Borb. et Waisb. & $\begin{array}{l}\text { M. } \times \text { dalmatica Tausch (longifolia } \times \text { arvensis) var. steffekiana } \\
\text { (Borb. et Waisb. 1895) Soó } 1966\end{array}$ \\
\hline Mentha globifera Waisb. et Borb. & $\begin{array}{l}\text { M. longifolia (L.) Nath. } 1756 \text { var. globifera (Waisb. et Borb. 1896) } \\
\text { Soó } 1966\end{array}$ \\
\hline
\end{tabular}

Erős egyénisége sohasem tagadta meg magát, s bár Borbás nagy hatással volt botanikusi működésének irányultságára, minden adatát épp oly kritikával fogadta, mint bármely más adatot. Igazolja ezt Kőszeg flórájának második kiadása is, melyben a kétesnek vélt fajok felülvizsgálatára Simonkai Lajost (1851-1910) kérte fel. Fajfelfogásában Borbás és Simonkai között állt. Abban, hogy konzervatív módon, de a „jónak” vélt újat mindig megfelelő kritikai érzékkel vette át, szerepet játszhatott Degen Árpáddal (1866-1934) való ismeretsége is, akivel harminc évig tartó levelező- és cserekapcsolatban állt. 
Waisbecker botanikai munkásságára a hazai botanikai-természetvédelmi irodalomban azóta is folyamatosan hivatkoznak, így például: BORBÁs $(1887,1898)$, BoROS (1927), JáVORKA (1929), Soó $(1934,1964)$, VisNYa (1940), JÁVORKA \& Soó (1951), HoRVÁth \& JEANPLONG (1962), PAPP (1962-64), JEANPLONG (1970), CSAPODY (1980), BARTHA et al. (1996), KiRÁly (1996, 2000), KovÁcs (1997), MolNÁR \& VidéKI (1999), BAUER \& KESZEI (2000), KESZEI (2005) és PifKó (2005), de egy újabb keletű, magyar-osztrák szerzőségű burgenlandi növényjegyzék sem feledkezik meg róla (SzABó et al. 2005).

Életművének jelentős hozadéka herbáriumi gyűjtőtevékenysége is. Részt vett Kerner Flora exsiccata austro-hungarica (GomBocz 1936), Kneucker Carices exsiccatae, Dörfler Herbarium normale, Baenitz Herbarium europaeum, Degen Cyperaceae, Juncaceae, Thyphaceae et Sparganiaceae Hungaricae exsiccata, Degen Gramina Hungarica gyüjtéseiben, így Kőszegen és környékén szedett növényei több hazai és külföldi herbáriumba is eljutottak (GÁYER 1916a).

Mintegy két és félezer lapra terjedő értékes gyűjteményt ajándékozott a szombathelyi Savaria Múzeum jogelődjének (WAISBECKER mscr. 1908, BODÁNYI 1910, GÁYER 1925, 1927, 1929b, HoRvÁTH 1958, 1963, S. PÁvEL 1964). „Mikor 1908-ban - elkészülvén Szombathelyen a Vasvármegyei Kultúregyesület múzeumának új palotája - arról volt szó, hogy a természetrajzi osztályt megalkossam, a növénytani anyag dolgában, mint legilletékesebbhez, Waisbecker Antal dr.-hoz fordultam. Ifjúi lelkesedéssel nyomban ajánlkozott, hogy kérésemnek eleget tesz és összeállítja eredeti példányokban Vasvármegye növénygyújteményét. Nem törődve egészségének megrokkanásával sem, hetven évvel vállán, de teljes erejével munkába állott, $s$ mintaszerüen rendezve, meghatározva hozta össze azt a nagy gyüjteményt, melyet önzetlenül a múzeumnak ajándékozott. Ez a tizenhat nagy csomóban letett herbárium két és félezer növényt tartalmaz, s ha más nem, egymagában minden időkre megörzi alkotójának a nevét" - írta az elhunyt tudósról a Kőszeg és Vidéke című lapban Chernel István, a Vasvármegyei Múzeum Természetrajzi Tárának ornitológus alapítója (CHERNEL 1916). Minderről, valamint további, Waisbeckerhez füződő vonatkozásokról Chernel - a FARAGÓ (2015) által napjainkban közölt naplóiban is ír.

A Vas Vármegye Flórája elnevezésű, de elsősorban Kőszeg vidékéről származó anyagot mai is itt, a szombathelyi Savaria Múzeumban őrzik (BALOGH 2001). Az utóbbi időkben revideált gyüjtemény PIERS VILMOStól való, közel négyszáz tételes kriptogám részét (BALOGH et al. 2004), továbbá Waisbecker gyüjtötte harasztjait (BALOGH et al. 2005) már közöltük, míg virágos anyagának feldolgozása - a XX. század utolsó negyedében előkerült további mintegy három és félszáz lapjával együtt (HoRVÁTH 1984, 1987) - folyamatban van (BALOGH et al. in prep.).

Botanikai gyűjteményének többi részét elhunyta évében örökösei a Magyar Nemzeti Múzeumnak ajándékozták, amelynek lapjai ma a Magyar Természettudományi Múzeum Növénytárának Herbarium Carpato-Pannonicum-ába vannak beosztva (ANONYM 1916d,e, JÁVORKA 1917). FEKETE \& KovÁTS (1974) szerint az I. világháború éveiben a legszámottevőbb ajándék, 1916-ban a Waisbecker-féle gyűjtemény volt (51 fasciculus). Mint írják, Kőszeg környéke, de egész Vas megye flórája szépen van képviselve benne. Genuszai között fajokban gazdagok a Carex, Potentilla, Rosa és Rubus, főleg a Borbással és Simonkaival való cseréi révén. A ma a Növénytárban lévő anyag becsült mennyisége 1700-1800 lap lehet (BARINA Zoltán in e-litt. 2015. aug. 12.).

Dr. Waisbecker Antal munkássága igen jelentősen járult hozzá ahhoz, hogy korában Kőszeg vidéke bírt az ország egyik legalaposabban feltárt flórájával. A XIX-XX. század fordulójának legjelentősebb Vas megyei botanikusaként nevét több növénytaxon is őrzi; ezek korabeli és újabb neveit GÁYER (1916a) és PRISZTER (1985) nyomán a 2. táblázat tartalmazza. A híres kőszegi „botanikus triász” egyikeként, noha tevékenysége túlnyomórészt Kőszeg 
környékére szorítkozott, jelentősége e térségen messze túlmutat. Nemes személyiségével, közéleti és botanikai munkásságával kiérdemelte, hogy Vas megye természettudósainak pantheonjába (HoRVÁTH et al. 1991), és Kőszeg Város legjelesebb emlékű polgárai közé kerüljön.

2. táblázat. A Dr. Waisbecker Antalról elnevezett taxonok és újabb nevük.

Table 2. Taxa and their recent synonyms, named after Dr. Antal Waisbecker.

\begin{tabular}{ll}
\hline \multicolumn{1}{c}{ Eredeti név / Original name } & \multicolumn{1}{c}{ Érvényes név / Valid name } \\
\hline $\begin{array}{l}\text { Carex cespitosa L. var. } \\
\text { Waisbeckeri Kükenthal }\end{array}$ & $\begin{array}{l}\text { Carex cespitosa L. subsp. waisbeckeri (Kükenthal 1901) } \\
\text { Jávorka 1924 }\end{array}$ \\
\hline Cirsium Waisbeckeri Simonkai & $\begin{array}{l}\text { Cirsium } \times \text { waisbeckeri Simonkai } 1891 \\
\text { (erisithales } \times \text { pannonicum) }\end{array}$ \\
\hline Mentha Waisbeckeri Borbás & $\begin{array}{l}\text { Mentha } \times \text { verticillata L. var. serotina (Host) Topitz } \\
\text { f. waisbeckeri Borbás 1893 nom. nud. 1897 icon }\end{array}$ \\
\hline Potentilla Waisbeckeri Siegfried & $\begin{array}{l}\text { Potentilla } \times \text { waisbeckeri Siegfried in Waisbecker 1891 nom. nud., } \\
\text { Borbás 1892, in Oborny 1900 (adscendens } \times \text { recta subsp. recta) }\end{array}$ \\
\hline Rosa Waisbeckeri Borbás & $\begin{array}{l}\text { Rosa tomentella Léman var. waisbeckeriana Borbás 1887 } \\
\text { (KenéNYI-NAGY 2012 szerint érvényessége kérdéses) }\end{array}$ \\
\hline Rubus Waisbeckeri Borbás & Rubus $\times$ waisbeckeri Borbás 1887 (caesius $\times$ tomentosus) \\
\hline Rubus Waisbeckeri Sudre [1905] & (syn. R. serpentini Sabr.) érvényessége kérdéses \\
\hline Rubus Antonii Borbás & $\begin{array}{l}\text { R. schleicheri Weihe in Boenningshausen 1824 } \\
\text { subsp. inaequabilis Sudre 1913 }\end{array}$ \\
\hline Viola riviniana Reichenbach f. & vizsgálandó \\
Waisbeckeri Gáyer 1916 &
\end{tabular}

\section{Köszönetnyilvánítás}

Ezúton mondunk köszönetet Király Gergelynek (Soproni Egyetem) és Papp Gábornak (MTM Könyvtár) egyes szakirodalmakhoz, Tóth-Barbalics Istvánnak (MTM Tudománytörténeti Gyűjtemény) és Márffyné Bardocz Emíliának (Kőszeg) pedig a Waisbecker-család hagyatékának néhány eredeti dokumentumához való hozzáférés lehetővé tételéért.

\section{Dr. Waisbecker Antal növénytani közleményeinek jegyzéke}

[KÜMMERLE (1916a) és az ezt átvett THIRRINGNÉ (1935) jegyzékeinek pontosításával és kibővítésével]

WAISBECKer A. (1882): Köszeg és vidékének edényes növényei. [Die Gefässpflänzen der Stadt Güns und deren Umgebung.] - Leitner Nándor könyvnyomdája, Kőszeg, 47 pp. - Ref.: BoRBÁs V. 1883, Botanisches Centralblatt 14: 270-271.

WAisBeCKer A. (1890): Új növénynem hazánk flórájában. [Eine neue Pflanzen-Gattung in der Flora Ungarns.] - Természettudományi Közlöny 22, XI. pótfüzet, pp. 142-143.

WAISBECKER A. (1891a): Zur Flora des Eisenburger Comitats. - Österreichische Botanische Zeitschrift 41(8-9): 278-279, 298-300. - Cf.: SchuBE, TH. 1894, Just's Bot. Jahresber. 1891, 19(2): 284.

WAIsBeCKER A. (1891b): Köszeg és vidékének edényes növényei. 2. javított és bővített kiadás. [Die Gefässpflänzen der Stadt Güns und deren Umgebung. Zweite verbesserte und vermehrte Auflage.] Feigl Gyula nyomdája, Kőszeg, 70 pp.; et: Kilián biz., Budapest, 80 pp. - Ref.: STAuB M. 1894, Just's Bot. Jahresber. 1891, 19(2): 337.

WAISBECKER A. (1892): Über die Büschelhaare der Potentillen. - Öst. Bot. Zeitschr. 42(8): 263-265.

WAisBeCKer A. (1893a): Beiträge zur Flora des Eisenburger Comitates. - Öst. Bot. Zeitschr. 43(8): 281282, (9): 317-319, (10): 354-357.

WAISBECKER A. (1893b): Néhány érdekesebb ibolya. [Über einige interessanteren Veilchen.] - Term.tud. Közl. 25. évf. 289. füzet, pp. 495-496.

WAISBECKER A. (1894): Carex Fritschii n. sp. - In: Sitzungsberichte. Verhandlungen der zoologisch- 
botanischen Gesellschaft in Wien 44(3-4): 51-52.

WAISBECKER A. (1895): Beiträge zur Flora des Eisenburger Comitates. - Öst. Bot. Zeitschr. 45(3): 109111, (4): 143-145.

WAisBeCKER A. (1897a): Beiträge zur Flora des Eisenburger Comitates. - Öst. Bot. Zeitschr. 47(1): 4-9.

WAISBECKER A. (1897b): Über die Variationen einiger Carex-Arten. - Öst. Bot. Zeitschr. 47(12): 429-433.

WAISBECKER A. (1897c): Carex caryophyllea Lat. var. caespitiformis Waisbecker. - In: KNEUCKER, A.: Bemerkungen zu den "Carices exsiccatae”. II. Lieferung, 1896. Allgemeine Botanische Zeitschrift 3(1): 10 .

WAisBeCKer A. (1897d): Carex Fritschii Waisbecker. - In: Kneucker, A.: Bemerkungen zu den „Carices exsiccatae". II. Lieferung, 1896. Allg. Bot. Zeitschr. 3(1): 11-12.

WAisBeCKer A. (1898a): Bemerkungen über Asplenium forsteri Sadl. - Öst. Bot. Zeitschr. 48(11): 419-423.

WAISBECKeR A. (1898b): Carex panicea L. var. praestabilis Waisbecker nov. var. - In: KNEUCKER, A.: Bemerkungen zu den „Carices exsiccatae”. IV. Lieferung, 1898. Allg. Bot. Zeitschr. 4(10): 163.

WAISBECKER A. (1899a): Beiträge zur Flora des Eisenburger Comitates. - Öst. Bot. Zeitschr. 49(2): 60-67, (3-4): 106-108, (5): 186-190.

WAISBECKER A. (1899b): Beiträge zur Kenntnis der Gattung Odontites. - Öst. Bot. Zeitschr. 49(12): 437-442.

WAISBECKER A. (1901a): Beiträge zur Flora des Eisenburger Comitates. - Öst. Bot. Zeitschr. 51(4): 125-132.

WAISBECKER A. (1901b): A bárcs-fajok eltérései és vegyült fajai Vasvármegyében. Die Variationen und Hybriden der Cirsium-Arten des Eisenburger Comitats in Ungarn. - Természetrajzi Füzetek 24(3-4): 332-344. - Ref.: ThaISZ L. 1903, Magyar Botanikai Lapok 2(1-2): 46-48.

WAisBecker A. (1901c): Carex caespitosa L. var. Waisbeckeri Kükenthal nov. var. - In: KneucKer, A.: Bemerkungen zu den „Carices exsiccatae”. IX. Lieferung, 1901. Allg. Bot. Zeitschr. 7(3): 53.

WAISBECKER A. (1902): Vasvármegye harasztjai. Die Farne des Eisenburger Comitats in West-Ungarn. Magyar Botanikai Lapok 1(5): 141-147, (6): 168-178, (7): 204-210, (8): 237-248. - et: Müller K. ny., Budapest, 17 pp. - Ref.: Degen Á. 1902, Botanisches Centralblatt 90(15): 423.

WAISBECKER A. (1903): Új adatok Vasvármegye flórájához. Neue Beiträge zur Flora des Comitats Vas in West-Ungarn, - Magy. Bot. Lapok 2(3): 63-79.

WAISBECKER A. (1904): Új adatok Vasvármegye flórájához. Neue Beiträge zur Flora des Eisenburger Comitats in West-Ungarn, - Magy. Bot. Lapok 3(3-5): 88-108.

WAISBECKER A. (1905): Új adatok Vasvármegye flórájához. Neue Beiträge zur Flora des Eisenburger Comitats in West-Ungarn, - Magy. Bot. Lapok 4(4-5): 54-78. - Ref.: KümmerLE J. B. 1906, Bot. Cbl. 101: 623 .

WAISBECKER A. (1906): Scirpus setaceus L. Vas vármegyében. Scirpus setaceus L. im Comitat Vas. - Magy. Bot. Lapok 5(5-7): 227-228.

WAISBECKER A. (1908): Új adatok Vasvármegye flórájához. Neue Beiträge zur Flora des Comitats Vas in West-Ungarn. - Magy. Bot. Lapok 7(1-3): 41-60.

WAISBECKER A. (mscr. 1908): A múzeum növénygyüjteményének névjegyzéke. Megjegyzések és magyarázatok. Kőszeg, 1908. szeptember hó 22-én. - Kézirat, Savaria Múzeum Természettudományi Osztály Kézirat- és Adattára, KT. 16.

WAISBECKen A. (1928): [Köszeg viránya.] - In: ThIRRING G.: Köszeg és környékének részletes kalauza. Turistaság és Alpinizmus Lap-, Könyv- és Térképkiadó R.-T., Budapest, p. 35. (posztumusz)

\section{Dr. Waisbecker Antallal kapcsolatos, válogatott irodalom}

ANONYm (1916a): Egy neves vasi botanikus halála. - Vasvármegye 49(81): 3 (ápr. 7.).

ANONYM (1916b): Alapítvány Waisbecker botanikus emlékére. - Vasvármegye 49(117): 4 (máj. 21.).

ANonym (1916c): Meghalt Dr. Waisbecker Antal. Dr. Anton Waisbecker gestorben. - Magyar Botanikai Lapok 15(1-5): 116-117.

Anonym (1916d): Dr. Waisbecker herbariuma a Nemzeti Muzeumban. - Köszeg és Vidéke 36(36): 2 (szept. 3.).

AnONYm (1916e): Kőszegi tudós gyűjteménye Budapesten. - Vasvármegye 49(206): 4 (szept. 5.).

ANonym (1916f): Dr. Waisbecker Antal [arckép]. - Magyar Botanikai Lapok 15(6-12): 136<->137.

Anonym (1918): Pályázati hirdetmény. - Köszeg és Vidéke 38(14): 2 (ápr. 7.).

Anonym (1937): A Waisbecker-család története. - Köszeg és Vidéke 57(34): 2 (aug. 22.). 
ANonym (1968): Dr. Waisbecker Antal orvos, botanikus [fénykép]. In: SzövÉNYI I.: Képek a dualizmus kori Kőszeg történetéből Chernel Kálmán naplói alapján. - Vasi Szemle 22(4): 571.

Anonym (1986): Gedenktag der Woche. - Burgenländische Freiheit 56(14): 24 (3 Apr.).

Ascherson P. \& Graebner, P. (1912): Synopsis der Mitteleuropäischen Flora. 2. Auflage. Erster Band Verlag von Wilhelm Engelmann, Leipzig, $629+98$ pp.

AumÜLLER S. (1956): Allgemeine Bibliographie des Burgenlandes. II. Teil. Naturwissenschaften. Burgenländisches Landesarchiv und Burgenländische Landesbibliothek, Eisenstadt, 93 pp.

B. IMREH J. (1985): Százötven éve született Waisbecker Antal. - Vas Népe, 1985. január 29., p. 5.

BALOGH L. (2001): Szombathely (SAMU): Herbarium, Department of Natural History, Savaria Museum, Szombathely, Hungary. - In: Holmgren P. K. \& Holmgren N. H. (eds), Additions to Index Herbariorum (Herbaria of the World), Edition 8 - Eleventh Series. Taxon, 50, May 2001, p. 609. Continuously updated web version: http://sweetgum.nybg.org/ih/herbarium.php?irn=125872

BAlOGH L. (2002): Waisbecker Antal (szócikk). - In: Bodó S. \& VIGA Gy. (szerk.), Magyar múzeumi arcképcsarnok. Életrajzok a magyar múzeumügy történetéből. Pulszky Társaság - Tarsoly Kiadó, Budapest, p. 951.

BALOGH L. (2006): Dr. Waisbecker Antal. - In: TóTH K. (szerk.), Elődeink. „Óriások vállán állunk.”Vasi Múzeumi Arcképcsarnok. http://muzeumbarat.hu/eletr.php? elod_id=17 (Hozzáférés: 2010. 02. 21.)

BALOGH L. (2010a): 175 éve született dr. Waisbecker Antal kőszegi orvos és botanikus. - Vasi Magazin, 2010. augusztus, p. 13.

BALOGH L. (2010b): 175 éve született Waisbecker Antal (1835-1916) kőszegi orvos és botanikus. Botanikai Közlemények 97(1-2): 175-176. (megjelent: 2011)

Balogh L., Király G. \& Mesterházy A. (in prep.): Herbarium Waisbeckerianum. 3. Waisbecker Antal herbáriumának virágos növényei a szombathelyi Savaria Múzeumban. (Herbarium Waisbeckerianum. 3. The anthophyte collection of Antal Waisbecker in the Savaria Museum, Szombathely.) - Praenorica Folia historico-naturalia (előkészületben).

BALOGH L., LŐKÖS L., PAPP B. \& VASAS G. (2004): Herbarium Waisbeckerianum. 1. Waisbecker Antal herbáriumának Piers Vilmos által összeállított gomba-, zuzmó- és mohagyűjteménye a szombathelyi Savaria Múzeumban. (Herbarium Waisbeckerianum. 1. The fungi, lichen and bryophyte collection of Vilmos Piers in the Savaria Museum, Szombathely.) - Savaria a Vas megyei Múzeumok Értesítője 28: 7-47. (megjelent: 2005)

Balogh L., Pintér I. \& Szerdahelyi T. (2005): Herbarium Waisbeckerianum. 2. Waisbecker Antal herbáriumának harasztjai a szombathelyi Savaria Múzeumban. (Herbarium Waisbeckerianum. 2. The pteridophyte collection of Antal Waisbecker in the Savaria Museum, Szombathely /SZO/.) Savaria a Vas megyei Múzeumok Értesítője 29: 7-43. (megjelent: 2006)

BARTHA D. (1994a): A Köszegi-hegység flóra- és vegetációkutatásának története. - In: BARTHA D. (szerk.), A Köszegi-hegység vegetációja I. - Saját kiadás, Kőszeg-Sopron, pp. 13-25.

BARTHA D. (szerk.) (1994b): A Kőszegi-hegység vegetációja I-II. - Saját kiadás, Kőszeg-Sopron, 200 pp. + XVII. tab. +3 térkép.

BARTha D., Bodonczi L., BölöNi J., Király G. \& Szmorad F. (1996): Változások a Kőszegi-hegység növényvilágában. (Veränderungen in der Pflanzenwelt des Günser-Gebirges.) - Vasi Szemle 50(2): 175-189.

BAUER N. \& KeSZEI B. (2000): Kiegészítések a Kőszegi-hegység flórájának és vegetációjának ismeretéhez. (Addenda to the knowledge of the vegetation of the Kőszeg-mountains.) - Vasi Szemle, 54(4): 547-553.

BoDÁNYI Ö. (1910): A Múzeum gyűjteményei. - In: Szombathely város fejlődése 1895-1910-ig és müszaki létesítményei. Építő ipar. Szombathely, pp. 195-199.

Borbás V. (1882): Vas megye tisztelt közönségéhez. - Vasmegyei Lapok 1882. no. 37. Et in: Bot. Cbl. 12: 301 (1882). - Öst. Bot. Zeitschr. 32 : 237 (1882). - Bot. Jahresb. 1882, 2: 586.

Borbás V. (1887): Vasvármegye növényföldrajza és flórája. (Geographia atque enumeratio plantarum comitatus Castriferrei in Hungaria.) (Flora und Pflanzengeographie des Komitates Eisenburg.) Vasmegyei Gazdasági Egyesület, Szombathely, 395 pp.

Borbás V. (1898): Vasvármegye növénygeográfiai viszonyai. (Geographia plantarum comitatus Castriferrei.) (Pflanzengeographische Verhältnisse des Komitates Eisenburg.) - In: SzIKLAY J. \& Borovszky S. (szerk.), Magyarország Vármegyéi és Városai, Vas vármegye. „Apollo” Irodalmi és Nyomdai Rt., Budapest, pp. 497-536. 
Boros Á. (1927): Vasvármegye moha-flórájának előmunkálatai. (Vorarbeiten zu einer Moosflora des Komitates Vas [Eisenburg].) - Vasvármegyei Múzeum Évkönyve 1926-27, 2: 207-224, 256-259.

CHERNEL I. (1916): Waisbecker Antal dr. 1835-1916. - Köszeg és Vidéke 36, 1916. ápr. 9., p. 2.

CSAPody I. (1980): A Kőszegi Tájvédelmi Körzet botanikai értékei. Die botanische Werte des Landschaftsschutzgebiet von Kőszeg. - Vasi Szemle 34(2): 290-294, 310.

Degen Á. (1914): Dr. Waisbecker Antal. In: Személyi hírek. Dr. Anton Waisbecker. In: Personalnachrichten. - Magyar Botanikai Lapok 13(1-5): 169-170.

Dostál J., Reichstein T., Fraser-Jenkins Ch. R. \& Kramer K. U. (1984): Pteridophyta. - In: Kramer, K. U. (hrsg.), Hegi's Illustrierte Flora von Mitteleuropa, Band I/1, 3., völlig neubearb. Aufl. Verlag Paul Parey, Berlin - Hamburg, 309 pp.

FARAGó S. (2015): Lélekkel teljesített hivatás. Chernelházi Chernel István naplója 1914-1922, 1-2. kötet. - Nyugat-magyarországi Egyetem Kiadó, Sopron, 494 pp., 609 pp, 2 app.

FEKETE G. \& KovÁTS D. (1974): A 100 éves Növénytár herbáriumainak története. II. Herbarium CarpatoPannonicum. In: Magyar Herbáriumok, 12. (rovatvezető: Priszter Sz.) - Botanikai Közlemények 61(3): 223-228.

FISCHER R. \& ADLER W. (1994): Excursionsflora von Österreich. Verlag Ulmer, Stuttgart - Wien, 1180 pp.

FisCHER R., AdLER W. \& OSWALD K. (2005): Excursionsflora von Österreich, Liechtenstein und Südtirol. Oberösterreichische Landesmuseum, Linz, 1373 pp.

FREH A. (1876): Kőszeg viránya. [Die Gefässpflänzen der Stadt Güns.] - Értesitvény a kôszegi kath. kisgymnasiumról 1875/6, pp. 3-33.

FREH A. (1883): Kőszeg és vidékének viránya. [Die Gefässpflänzen der Stadt Güns und deren Umgebung.] - Értesitô a kőszegi kath. kisgymnasiumról 1882/3, pp. 3-63.

GÁYER GY. (1916a): Dr. Waisbecker Antal. Emlékezés (Arczképpel). Ein Nachruf (Mit Portrait). - Magyar Botanikai Lapok 15(6-12): 207-212.

GÁYER Gy. (1916b): Viola Riviniana Reichb. forma Waisbeckeri n. f. - Magyar Botanikai Lapok 15(6-12): 270-271.

GÁYeR Gy. (1925): III. Természetrajzi osztály. - In: Miske K.: A Vasvármegyei Múzeum. Vasvármegyei Múzeum Évkönyve (Annales Sabarienses) 1925, 1: 57-63.

GÁYER Gy. (1927): A Vasvármegyei Múzeum növénytani gyűjteményei I-II. - Vasvármegye 60: 4 (okt. 23.), 60: 5 (okt. 30.).

GÁYer J. (1929a): Die Pflanzenwelt der Nachbargebiete von Oststeiermark. - Mitteilungen des naturwissenschaftlichen Vereins für Steiermark 64-65: 150-177, $2 \mathrm{tt}$.

GÁYER Gy. (1929b): A Vasvármegyei Múzeum jelentései. E) Természetrajzi tár. - Vasvármegyei Múzeum Évkönyve (Annales Sabarienses) 1927-29, 3: 40-41.

Gомвосz E. (1936): A magyar botanika története. A magyar flóra kutatói. - Magyar Tudományos Akadémia, Budapest, 636 pp.

HorvÁth E. (1958): A szombathelyi Savaria Múzeum (Az épület fennállásának 50. évfordulójára). - Vasi Szemle 12(2): 120-127.

HoRvÁTH E. (1963): Adatok Chernel István életrajzához, Chernel-jegyzetek alapján. Angaben zu István Chernels Lebensgeschichte, auf Grund Tagebuchnotizen von István Chernel. - Savaria a Vas megyei Múzeumok Értesítője 1963, 1: 57-83.

HoRvÁTH E. (1984): Jelentés a Vas megyei Múzeumok 1979-80. évi munkájáról. Savaria Múzeum, Szombathely, Természettudományi Osztály. Savaria Museum, Szombathely, Naturwissenschaftliche Abteilung 1979-1980. - Savaria a Vas megyei Múzeumok Értesítője 1979-1980, 13-14: 495-500, 501-506.

HoRvÁTH E. (1987): Az Alpokalja-kutatás kilenc esztendeje. Die neun Jahre der Forschung von Alpokalja (Voralpengebiet). - Praenorica folia historico-naturalia, Szombathely, 2: 11-20.

Horváth E. (kezdeményezte), Simon Gy. (plexikarcok), Istók E. (kiadó), Szabó T. Attila (szerk.), SzABó T. Anna (angol változat) (1991): Természettudósok arcképcsarnoka, Vas megye: Élettudományok, földtudományok, fizika, csillagászat, határtudományok, honismeret. - BioTár (BDTF, Szombathely), VIII, $16+20$ pp., 43 arckép.

JÁvorKa S. (1917): A Magyar Nemzeti Múzeum növénytárának újabb gyarapodása. Neuere Bereichung der botanischen Abteilung des Ungarischen Nationalmuseums. - Botanikai Közlemények, 16(1-3): 40-41, (18)-(19). Ref.: D[EGEN Á.] (1917), Magyar Botanikai Lapok, 16(1-12): 153. 
JÁVoRKa S. (1929): Az Eragrostis mexicana (Lag.) Lk. Magyarországon. Über das Vorkommen von Eragrostis mexicana (Lag.) Lk. in Ungarn. - Botanikai Közlemények 26(1-4): 32-33.

Jávorka S. (1940): A Carex Fritschii Waisb.-ről. Über Carex Fritschii Waisb. - Tisia 4: 148-150.

JávorKa S. (1924-1925): Magyar Flóra (Flora Hungarica). - Studium, Budapest, CII + 1307 pp.

JEANPLONG J. (1970): Geobotanische Untersuchungen in Mittel- und Südburgenland. - Wissenschaftlichen Arbeiten aus dem Burgenland (Eisenstadt), Heft 44, pp. 108-125.

JEANPLONG J. (1981): Vas megye botanikai kutatásának helyzete az utóbbi 100 év folyamán. (Die Lage der botanischen Forschungen über das Komitat Vas in den letzten 100 Jahren.) - Alpokalja Természeti Képe 1. Közlemények 1976-1981, Szombathely, pp. 35-38.

KERÉNYI-NAGY V. (2012): A Történelmi Magyarország területén élő őshonos, idegenhonos és kultúrreliktum rózsák kismonográfiája. - NYME Egyetemi Kiadó, Sopron, 434 pp.

Keszei B. (2005): A tavaszi orgona és a bariszőlő, avagy megőrizhető-e a Kőszegi Tájvédelmi Körzet botanikai gazdagsága? - Vasi Szemle 59(6): 679-689.

KIRÁLY G. (1996): A Kőszegi-hegység edényes flórája. [Die Gefässpflanzenflora des Günser Gebirges.] Tilia 3: 1-414, 2 térkép.

KIRÁLY G. (2000): Neue Ergebnisse der floristischen Forschung im westlichen Grenzgebiet Ungarns. Verhandlungen der Zoologisch-Botanischen Gesellschaft Österreich 137: 235-253.

KISs Gy. (1958): Waisbecker Antal. In: Vasiak a tudomány szolgálatában. In: HoRváth F. (szerk.), Vas megye. Helytörténeti tanulmányok. - Vas m. Tanácsa V. B., Szombathely, (386 pp.), p. 237.

KovÁCS J. A. (1997): Szemelvények a vasi térség flórájának-vegetációjának ismeretéhez. (Zur Kenntnis der Flora und Vegetation im Eisenburger Raum.) - Vasi Szemle 51(3): 285-298. et in: Botanikai Közlemények, 84(1-2): 147-157.

KüMmERLE J. B. (1916a): Publicationes Dris A. Waisbecker. - Magyar Botanikai Lapok 15(6-12): 212-213.

KüMmerle J. B. (1916b): Nomenclator Waisbeckerianus. - Manuscript. Savaria Múzeum Természettudományi Osztály Kézirat- és Adattára, Szombathely (SM-TtO KT), KT.58.

LÄMmeRMAYR L. (1928): Weitere Beiträge zur Flora der Magnesit- und Serpentinböden. Sitzungsberichten der Akademie der Wissenschaften in Wien, Mathem.-naturw. Klasse, Abteilung I, 137(1-2): 55-99.

Litschauer G. F. (1964): Allgemeine Bibliographie des Burgenlandes. III. Teil. Geographie. Burgenländisches Landesarchiv und Burgenländische Landesbibliothek, Eisenstadt, 449 pp.

MÁGocSY-DieTz S. (1916): Az elnök bejelentése Dr. Waisbecker Antal elhunytáról. In: A növénytani szakosztály 1916 április 12-én tartott 212. ülése [summ.: SzABó Z.]. - Botanikai Közlemények, 15(3-4): $121,(34)$.

MeLzER H. (1962): Floristisches aus Niederösterreich und dem Burgenland, IV. - Verhandlungen der zoologisch-botanischen Gesellschaft, Wien 101/102: 192-200.

Merkuin T. (1997): A hét műtárgya: Waisbecker Antal tintatartója. (fényképpel) - Vas Népe, 42(40): 7 (febr. 17.).

MoLNÁR V. A. \& VIDÉKI R. (összeáll.) (1999): Felhasznált és ajánlott irodalom. In: FARKAS S. (szerk.), Magyarország védett növényei. - Mezőgazda Kiadó, Budapest, pp. 361-389.

PAPP J. (1962-64): Vas megye természeti értékeivel foglalkozó irodalom bibliográfiája. I-II. - Vasi Szemle I. rész: 16(1): 131-139; II. rész: 18(2): 307-316.

Piers V. (1890): Nachtrag zu Dr. Vinc. v. Borbás "Geographia atque enumeratio plantarum comitatus Castriferrei in Hungaria". - Österreichische Botanische Zeitschrift 40(6): 243-246.

PIFKó D. (2005): Taxonomic revision and typification of Cytisus (Leguminosae) in the Herbarium Carpato-Pannonicum in Budapest (BP). - Annales Historico-Naturales Musei Nationalis Hungarici 97: 21-32.

S. PÁvel J. (1964): A szombathelyi Savaria Múzeum története. (Die Geschichte des Savaria Museums.) Savaria, a Vas megyei Múzeumok Értesítője 1964, 2: 293-319.

PRISZTER Sz. (1985): A magyar flóra és vegetáció rendszertani-növényföldrajzi kézikönyve VII. Kiegészítések és mutatók az I-VI. kötethez. (Synopsis systematico-geobotanica florae vegetationisque Hungariae VII. Addenda indicesque ad tomos I-VI.) - Akadémiai Kiadó, Budapest, 683 pp.

SAUERzopf F. (1983): Der Stand der botanischen Erforschung des Burgenlandes. - Forum Pannonicum rerum naturarum (Illmitz) 1: 43-47.

Soó R. (1934): Vasmegye szociológiai és florisztikai növényföldrajzához. (Zur soziologischen und floristischen Pflanzengeographie des Komitates Vas in Westungarn.) - Vasi Szemle 1(2): 105-134. 
Soó R. (1964): A magyar flóra és vegetáció rendszertani-növényföldrajzi kézikönyve I. (Synopsis systematico-geobotanica florae vegetationisque Hungariae I.) - Akadémiai Kiadó, Budapest, 589 pp.

SöPTEI I. (2000): Deák Ferenc emléke Kőszegen. Egy alapítvány története (1876-1934). - Köszegi Lapok 5. szám, pp. 1-4.

Szabó I., Wolkinger F. \& Breitegger E. (eds) [s. a. (2005)]: Liste der Farn- und Blütenpflanzen des Burgenlandes. Überarbeitung der Fassung Traxler 1989 ergänzt durch deutsche und ungarische Namen von Eduard Weber. - Veröffentlichungen der Internationalen Clusius Forschungsgesellschaft, Güssing, 9: 1-51, 8 col. tab.

THiRRING G. (1928): Köszeg és környékének részletes kalauza. - Turistaság és Alpinizmus Lap-, Könyv- és Térképkiadó R.-T., Budapest, 80 pp.

THiRRing G. (1933): Szombathely és környékének részletes kalauza. - Turistaság és Alpinizmus Lap-, Könyv- és Térképkiadó Rt., Budapest, 32 pp. (p. 18.)

ThIRRING G.-NÉ WAISBECKER I. (1935): Dr. Waisbecker Antal élete. In: Dr. Waisbecker Antal és családja. Családtörténeti életképek. In: Dr. Waisbecker Antal élete és a magyarországi Waisbecker család története (40 képpel). - Székely és Társa Könyvnyomdája, Sopron, 50 pp. (Autorref.: Családtörténeteink. - In: Vasi Szemle 5(1-2): 87-88, 1938.)

THIRRING G.-NÉ WAISBECKER I. (1937): Újabb adatok a magyarországi Waisbecker-család történetéhez és egyéb családi emlékek (8 képpel). - Székely és Társa Könyvnyomdája, Sopron, 20 pp. (Autorref.: Vasi Szemle, 1938, 5(1-2): 87-88.)

Tótн G. (1991): 75 éve hunyt el Kőszeg kiemelkedő polgára. „Orvostudor” majd botanikus. Waisbecker herbáriuma. - Köszeg és Vidéke 4(4): 4 (ápr.).

Vende E. (1898): Dr. Waisbecker Antal. - In: Bonovszky S. (szerk.), III. Vasvármegye. In: Sziklay J. \& Borovszky S. (szerk.), Magyarország vármegyéi és városai. Apollo, Budapest, pp. 349-350.

VIG K. (1999): Vas megye élővilágának megismerése, jelenkori természeti értékei. (History of the botanical and zoological survey of county Vas /Western Hungary/ and recent natural values of the territory.) - Savaria, a Vas megyei Múzeumok Értesítője 25/2: 7-82.

ViSNYA A. (1940): Érdekesebb harasztok új lelőhelyei Vas megyében. Neue Fundorte von interessanteren Farnen im Comitate Vas (Eisenburg). - Dunántúli Szemle (Szombathely) 7(5-6): 278-282.

Beérkezett / received: 2015. 11. 02. • Elfogadva / accepted: 2015. 11. 12. 